\title{
Response of Stages of Harvesting and Post Harvest Ripening Duration to Seed Quality in Bottle Gourd [Lagenaria siceraria (Mol.) Standl.]
}

\author{
Neha Kumari Gupta ${ }^{1}$, Vijay Kumar Singh ${ }^{1 *}$, R. B. Verma ${ }^{1}$, \\ Randhir Kumar ${ }^{1}$, Mukesh Kumar ${ }^{2}$ and Sanjay Kumar ${ }^{3}$ \\ ${ }^{1}$ Department of Hort. (Veg. and Flori.), ${ }^{2}$ Deparment of Seed Science and Technology, \\ ${ }^{3}$ Department of Agronomy, BAU, Sabour, India \\ *Corresponding author
}

\begin{abstract}
A B S T R A C T
The experiment on response of stages of harvesting and post harvest ripening duration to seed quality in bottle gourd [Lagenaria siceraria (Mol.) Standl.] was carried out during

Keywords

Bottle gourd,

Harvesting stages,

Post harvest

ripening, Seed

quality

Article Info

Accepted:

20 December 2020

Available Online:

10 January 2021 summer, 2019. The treatments consist of three stages of fruit harvesting 40,50,60 days after anthesis (DAA), four stages of post harvest ripening (no post harvest ripening, 10 days PHR, 20 days PHR, 30 days PHR) and their combinations. Significantly maximum germination $(84.13 \%)$, seedling length $(23.57 \mathrm{~cm})$, seedling dry weight $(206.76 \mathrm{mg})$, moisture content (8.82\%), vigour index-I (1898.10) and vigour index -II (17628.26) and low electrical conductivity $(0.498 \mathrm{dSm}-1 \mathrm{~g}-1)$ were recorded in $\mathrm{H} 2$ (fruit harvested 50 days after anthesis) whereas the highest germination $(74.95 \%)$, seedling length $(22.16 \mathrm{~cm})$, seedling dry weight (206.09 mg), vigour index-I (1702.25) and vigour index-II (16070.48) and low electrical conductivity $(0.552 \mathrm{dSm}-1 \mathrm{~g}-1)$ were obtained in P2 ( 20 days post harvest ripening ). Response of stages of harvesting at 50 days after anthesis and postharvest ripening of 20 days (H2P2) gave good seed quality with significantly maximum germination $(95.33 \%)$, seedling length $(27.23 \mathrm{~cm})$, seedling dry weight $(258.29 \mathrm{mg})$ and least electrical conductivity of seed leachates $(0.424 \mathrm{dSm}-1 \mathrm{~g}-1)$ Hence, it may be concluded that bottle gourd should be harvested at 50 days after anthesis and 20 days post harvest ripening for production of better seed quality.
\end{abstract}

\section{Introduction}

Bottle gourd (Lagenaria siceraria (Molina) standl.] is an important cucurbitaceaous crop mainly grown throughout the year in tropical and subtropical regions. It is cultivated both in kharif and summer seasons. Seed is the most precious, basic and essential input for increasing crop production. A quality seed assures a successful crop production and the yield may be increased up to $15-20 \%$ (Ambika et al., 2014). In gourds family, flowering mainly take place in an indeterminate habit thus fruits and seeds of different stages of maturity are present on the same plant, therefore, in bottle gourd development of fruit and attainment of physiological maturity takes place at different times (Kanwar, 2001). Fruits harvested even before completion of physiological maturity 
and allowed for post-harvest ripening for some days also gives good quality seeds because inside the fleshy fruits the development of seed takes place by getting continuous supply of nutrients and food from fruits (Karnataka, 2008) and Passam et al., (2010). Post-harvest ripening duration and environment controlled the process occurring in the dry seeds, which ascertain the germination potential of seeds (Carriera, et al., 2008).

For seed purpose seed crop may be successfully cultivated but the appropriate stage of harvesting is an important factor because any deviation from appropriate stage of harvesting it may leads to loss of seed yield and quality of seed. Therefore, to obtain maximum seed yield with good quality of seed it should be harvested at appropriate stage of maturity pretend more importance rather than cultural practices, climate and soil (Delouche. 1980).

\section{Materials and Methods}

The field experiment was conducted for quality seed production of bottle gourd cv. Narendra Rashmi at the experimental farm of Department of Horticulture (vegetable and Floriculture), Bihar Agricultural University, Sabour (Bihar) during summer, 2019. The fruits were harvested at three different stages viz; $\mathrm{H}_{1}-40$ days after anthesis (DAA), $\mathrm{H}_{2}-50$ DAA and $\mathrm{H}_{3}-60$ DAA and four post-harvest ripening duration i.e. $\mathrm{P}_{0}$-no post-harvest ripening period (PHR), $\mathrm{P}_{1^{-}}-10$ days $\mathrm{PHR}, \mathrm{P}_{2^{-}}$ 20 days $\mathrm{PHR}$ and $\mathrm{P}_{3}-30$ days $\mathrm{PHR}$. Seed extracted from the randomly selected fruit were used for taken observations such as germination percent, seedling length, moisture percent, seedling dry weight, vigour index-I and II. Germination test was conducted in the laboratory as per the ISTA procedure with100 seeds from each treatment and each replication. Seed lots were taken and placed on germination paper and rolled. The rolled germination papers were kept in germinator at $25 \pm 1^{\circ} \mathrm{C}$ temperature and $95 \pm 1^{\circ} \mathrm{C}$ percent relative humidity. The first count of germination was taken at 6 days and the final count was noted at 14 days and then number of seedlings were counted and expressed in per cent.

The seedling length was calculated by adding both root and shoots lengths of ten normal seedling from each treatment and replication. The ten seedling were dried at $80^{\circ} \mathrm{C}$ for 24 hours and weighed by using electronic balance. The vigour indices I and II were calculated by using formula suggested by Abdul Baki and Anderson (1973).

Vigour index-I $=$ Germination $\% \times$ seedling length $(\mathrm{cm})$

Vigour index-II $=$ Germination $\% \times$ seedling dry weight (mg)

Treatment wise 100 seeds were soaked in 250 $\mathrm{ml}$ distilled water in a beaker. Covered the beaker with aluminium foil and kept for 24 hours at $25 \pm 1^{\circ} \mathrm{C}$. The seeds leachates were collected and electrical conductivity were measured with the help of digital conductivity meter

\section{Results and Discussion}

The main effect of harvesting stages had significant influence on seed quality parameters viz; germination, seedling length, seedling dry weight, moisture content in seed, electrical conductivity, vigour index-I and vigour index-II. The fruit harvested at 50 days after anthesis gave maximum germination (95.33\%), seedling length $(22.93 \mathrm{~cm})$, seedling dry weight (217.52 mg), vigour index-I (1935.30), vigour index-II (18607.26), low moisture content $(9.08 \%)$ with least electrical conductivity $\left(0.498 \mathrm{dSm}^{-1} \mathrm{~g}^{-1}\right)$. 
Table.1 Influence of stage of harvest and post-harvest ripening duration on seed quality parameters in bottle gourd cv. Narendra Rashmi

\begin{tabular}{|c|c|c|c|c|c|c|c|}
\hline Treatment & $\begin{array}{c}\text { Germination } \\
\%\end{array}$ & $\begin{array}{l}\text { Seedling } \\
\text { length } \\
\text { (cm) }\end{array}$ & $\begin{array}{l}\text { Seedling dry } \\
\text { weight (mg) }\end{array}$ & $\begin{array}{l}\text { vigour } \\
\text { index-I }\end{array}$ & $\begin{array}{l}\text { vigour } \\
\text { index-II }\end{array}$ & $\begin{array}{c}\text { Moisture } \\
\text { content } \\
(\%)\end{array}$ & $\begin{array}{l}\text { Electrical } \\
\text { conductivity } \\
\left(\mathrm{dSm}^{-1} \mathrm{~g}^{-1}\right)\end{array}$ \\
\hline \multicolumn{8}{|c|}{ Effect of different stage of Harvest } \\
\hline $\mathbf{H}_{1}$ & 56.08 & 15.66 & 130.87 & 888.11 & 7401.93 & 9.61 & 0.704 \\
\hline $\mathrm{H}_{2}$ & 84.13 & 22.93 & 217.52 & 1935.30 & 18607.26 & 9.08 & 0.498 \\
\hline $\mathbf{H}_{3}$ & 71.25 & 23.02 & 212.56 & 1643.42 & 14760.79 & 8.97 & 0.554 \\
\hline CD at $5 \%$ & 3.30 & 1.19 & 10.01 & & 769.78 & 0.45 & 0.032 \\
\hline \multicolumn{8}{|c|}{ Effect of post harvest ripening duration } \\
\hline $\mathbf{P}_{\mathbf{0}}$ & 63.00 & 17.61 & 165.56 & 1163.52 & 10777.14 & 9.67 & 0.633 \\
\hline $\mathbf{P}_{1}$ & 69.11 & 20.90 & 176.30 & 1448.44 & 12030.38 & 9.27 & 0.598 \\
\hline $\mathbf{P}_{2}$ & 74.89 & 22.85 & 209.74 & 1771.36 & 16418.43 & 9.07 & 0.557 \\
\hline $\mathbf{P}_{3}$ & 74.95 & 20.79 & 196.32 & 1572.44 & 15134.01 & 8.85 & 0.552 \\
\hline CD at $5 \%$ & 3.81 & 1.38 & 11.56 & 132.44 & 888.86 & 0.52 & 0.037 \\
\hline \multicolumn{8}{|c|}{ Interaction effect of stage of harvest and post harvest ripening duration } \\
\hline $\mathbf{H}_{1} \mathbf{P}_{0}$ & 47.33 & 10.49 & 116.32 & 496.48 & 5468.75 & 10.24 & 0.762 \\
\hline $\mathbf{H}_{1} \mathbf{P}_{1}$ & 54.00 & 16.53 & 125.37 & 892.62 & 6769.98 & 9.74 & 0.733 \\
\hline $\mathrm{H}_{1} \mathbf{P}_{2}$ & 58.33 & 17.06 & 134.45 & 995.09 & 7842.45 & 9.50 & 0.685 \\
\hline $\mathbf{H}_{1} \mathbf{P}_{3}$ & 64.67 & 18.58 & 147.31 & 1168.23 & 9526.53 & 8.95 & 0.635 \\
\hline $\mathrm{H}_{2} \mathrm{P}_{0}$ & 73.67 & 20.28 & 176.17 & 1494.01 & 12978.43 & 9.49 & 0.552 \\
\hline $\mathrm{H}_{2} \mathbf{P}_{1}$ & 78.00 & 21.16 & 188.25 & 1567.95 & 14683.50 & 9.09 & 0.533 \\
\hline $\mathrm{H}_{2} \mathbf{P}_{2}$ & 95.33 & 27.23 & 258.29 & 2595.82 & 24622.77 & 8.90 & 0.424 \\
\hline & 89.53 & 23.04 & 247.34 & 2083.39 & 22144.34 & 8.82 & 0.482 \\
\hline $\mathbf{H}_{2} \mathbf{P}_{3}$ & 68.00 & 22.06 & 204.18 & 1500.08 & 13884.24 & 9.29 & 0.585 \\
\hline $\mathbf{H}_{3} \mathbf{P}_{\mathbf{0}}$ & 75.33 & 25.02 & 215.26 & 1884.75 & 14637.68 & 9.00 & 0.527 \\
\hline $\mathbf{H}_{3} \mathbf{P}_{1}$ & 71.00 & 24.27 & 236.48 & 1723.16 & 16790.08 & 8.81 & 0.563 \\
\hline $\mathbf{H}_{3} \mathbf{P}_{2}$ & 70.67 & 20.74 & 194.30 & 1465.69 & 13731.17 & 8.97 & 0.557 \\
\hline \multicolumn{8}{|l|}{$\mathbf{H}_{3} \mathbf{P}_{3}$} \\
\hline CD at $5 \%$ & 6.60 & 2.39 & 20.03 & 229.40 & 1539.57 & 0.91 & 0.064 \\
\hline
\end{tabular}

The better seed quality parameters at $\mathrm{H}_{2}$ stage (fruits harvested at 50) probably due to fruit harvested at this stage attained physiological maturity as compared to other stages of harvest and also seed at this stage have more dry matter accumulation which increases the ability of seeds to germinate. The minimum value was recorded in early stage of harvesting i.e, $40 \mathrm{DAA}$. This might be due to more number of immature and under developed seeds. These results are in agreement with findings of Kalyanrao et al., (2014) in bottle gourd and Devaraju et al., (2013) in cucumber. The individual effect of post harvest ripening also caused significant effect and produced maximum germination $(74.89 \%)$, seedling length $(22.85 \mathrm{~cm})$, seedling dry weight (209.74mg), vigour index-I (1771.36), vigour index-II (16418.43), low moisture content in seed $(8.85 \%)$ with minimum electrical conductivity $\left(0.552 \mathrm{dSm}^{-}\right.$ ${ }^{1} \mathrm{~g}^{-1)}$. These results are similar the findings of Maruthi et al., (2014) in bottle gourd and Kanwar (2001) in cucumber.

The interaction effect of stage of harvest and post harvest ripening duration was found significant and maximum germination (95.33\%), seedling length $(27.23 \mathrm{~cm})$, seedling dry weight $(258.29 \mathrm{mg})$, vigour index-I (2595.82), vigour index-II (24622.77), minimum moisture content in seed $(8.82 \%)$ with lower electrical conductivity $(0.424$ $\left.\mathrm{dSm}^{-1} \mathrm{~g}^{-1}\right)$. These results are in consonance 
with the findings of Ahmed et al., 2007) in chilli and Vidigal et al., (2006) into mato.

In conclusion on the basis of present investigation it can be concluded that fruits of bottle gourd should be harvested at 50 days after anthesis and allow to20 days post harvest ripening gave better result for getting seed quality parameters.

\section{References}

Ambika, S., Manonmani, V. And Somasundaram, G. (2014). Review on the effect of seed size on seedling vigour and yield. Research Journal of Seed Science., 1:1-8.

Carrera E, Holman, Medhurst T, Dietrict A, Footitt D, Theodoulou S, Holdsworth F.L and Holdsworth M.J.(2008). Seed after-ripening is a discrete developmental pathway associated with specific gene networks in Arbidopsis. The plant Journal. Vol 53(2):214-224 Jan.2008.

De Souza VD, Dias Dos Santos DCF, Carrero NDDSP, Branco RF, Carmen BM.(2006). Physiological quality of tomato seeds in relation to fruit age and post- harvest storage. Revista. Brasileirade Sementes. 28 (3): 87-93.

Delouche J.C, 1980.Environmental effects on seed development and seed quality. Hortscience, 15:775-780.

Devaraju P J, Chetan H N and Dinesh H B. (2013). Influence of fruit harvesting stage on seed quality of cucumber (Cucumis sativus L.) cv. Hassan Local.
International Journal of Agricultural Sciences 9(2): 636-639.

ISTA, (2008).Seed testing rules, The International Seed Testing Association8303, Barsserssorf, CH-Switzerland.

Kalyanrao, Tomar B S and Singh B. (2014). Effect of stage of harvesting and post harvest ripening on hybrid seed yield and quality in bottle gourd. Indian Journal of Horticulture 71(3):428-432.

Kanwar J S. (2001). Effect of stage of harvest and post harvest curing on seed quality of cucumber. Haryana Journal of Horticultural Sciences 30(3):244-246.

Karnataka, J. (2008). Influence of stage of harvest and post-harvest ripening periods on seed quality in paprika chilli (Capsicum annuum L.). Agricultural Science, 21(2): 266-269.

Maruthi K, Doddagoudar S R, Vasudevan S N, KhidrapureG and Hanumanthappa D. (2014). Effect of post harvest ripening duration on seed quality during storage in bottle gourd (Lagenaria siceraria). The Ecoscan6: 209-215.

Passam H C, Theodoropoulou S, Karanissa T and Karapanos I C. (2010). Influence of harvest time and after-ripening on the seed quality of eggplant Scientia Horticulturae 125(3) 518-520.

Shamsheer A, A M.2007. Effect of growth regulators and stages of fruit harvest on seed yield and quality in paprika chilli (Capsicum annuum L.) cv. Kt-Pl-19. M.SC. (Agri.) Thesis, University of Agricultural Sciences, Dharwad, Karnataka, India.

\section{How to cite this article:}

Neha Kumari Gupta, Vijay Kumar Singh, R. B. Verma, Randhir Kumar, Mukesh Kumar and Sanjay Kumar. 2021. Response of Stages of Harvesting and Post Harvest Ripening Duration to Seed Quality in Bottle Gourd [Lagenaria siceraria (Mol.) Standl.]. Int.J.Curr.Microbiol.App.Sci. 10(01): 3376-3379. doi: https://doi.org/10.20546/ijcmas.2021.1001.397 